\title{
Correction to "Identification of Serine-875 as an Inhibitory Phosphorylation Site in the Calcium-Sensing Receptor"
}

In the above article [Binmahfouz LS, Centeno PP, Conigrave AD, and Ward DT (2019) Mol Pharmacol 96 (2): 204-211; DOI: https://doi.org/10.1124/mol.119.116178], two 'n' values were found to be missing from figure 2 caption. The corrected Figure 2 caption is provided below. The HTML and PDF version of the article have been corrected.

The authors regret this error and any inconvenience it may have caused.

Figure 2: $\mathrm{CaS}^{\mathrm{T} 888 \mathrm{~A}}$ and $\mathrm{CaS}^{\mathrm{S875A}}$ mutations increase CaS-induced ERK1/2 phosphorylation. A) HEK-293 cells were stably transfected with either CaS ${ }^{\mathrm{WT}}, \mathrm{CaS}^{\mathrm{T} 888 \mathrm{~A}}$ (i) or $\mathrm{CaS}^{\mathrm{S} 875 \mathrm{~A}}$ (ii), then stimulated with various $\mathrm{Ca}_{\mathrm{o}}^{2+}$ concentrations $(0.5-5 \mathrm{mM})$ for $10 \mathrm{mins}$ to determine the effect of mutating the two phosphorylation sites on ERK activation. Representative western blots indicating ERK1/2 phosphorylation, together with $\beta$-actin loading control are shown above the resulting concentration-effect curves for each. ERK1/2 responses are expressed as a $\%$ of the $\mathrm{CaS}^{\mathrm{WT}}$ maximal response in each experiment. $* * \mathrm{P}<0.01 \mathrm{CaS}^{\mathrm{T} 888 \mathrm{~A}}$ vs $\mathrm{CaS}^{\mathrm{WT}}$ ( $\mathrm{n}=6$ from three independent experiments) and $\mathrm{CaS}^{\mathrm{S} 875 \mathrm{~A}}$ vs $\mathrm{CaS}^{\mathrm{WT}}$ ( $\mathrm{n}=7$ from three independent experiments) $\mathrm{pEC}_{50}$ values by unpaired t-test. B) CaS immunoblots showing similar receptor abundance between cell lines, with their protein loading equivalence confirmed by $\beta$-actin expression. 